\title{
Biopsy of Brain
}

National Cancer Institute

\section{Source}

National Cancer Institute. Biopsy of Brain. NCI Thesaurus. Code C51766.

Removal of brain tissue for microscopic examination. 